\title{
Research on the Recycling Strategy of Used Textbooks in Colleges and Universities
}

\author{
Xu Xianjin, Zhu Yanlong, Liu Hao, Liu Min \\ College of Mechanical Engineering \\ Hubei University of Technology \\ Wuhan, China \\ E-mail:xxjoyjn@126.com
}

\begin{abstract}
In order to improve the utilization rate of China's second-hand textbooks in Universities, promote the second-hand textbooks' recycling process, through the use of market research, in Hubei University of technology as an example the operation mode of the existing old bookstore started research work. In the survey, we for all the students randomly distributed questionnaires and we made an in-depth interview with three old bookstores. And after these works we use " $5 \mathrm{~W} 1 \mathrm{H}$ " questioning technology, analysis and improvement of the problems existing in the system of the current second-hand textbooks circulating use. Design a comprehensive colleges and universities, intermediate platform, student group third party deeply involved in sharing information resources used college textbooks circulating utilization system, expand the influence and coverage of the intermediate platform, will be used college textbooks circulating utilization projects to achieve economies of scale, set up a professional sorting, repair, disinfection etc. workflow, solve the second-hand textbooks circulating use of health problems, improve the utilization rate of the textbook.
\end{abstract}

Keywords-second-hand textbook recycling system; 5W1H; sharing information

\section{INTRODUCTION}

According to the relevant data show that, in China in 2015 the scale of students has reached 37 million people, at this level of the scale of students, the annual consumption of the quantity of materials is to the point quite amazing. However, in fact this teaching material life basically only about a semester, which for forest resources in our country is not rich situation has the potential threat. Currently in Europe and the United States developed countries, has long been used in the recycling of textbooks to establish a relatively complete system of [1], the effective improvement of the life of the teaching materials. But in our country although in 2006 has introduced a does not allow the university to forcibly collect materials of prepayment policy, provides a good policy support used college textbooks circulating use. However, until today, the domestic used college textbooks circulating utilization is still poor. Thereon, this paper from the second-hand materials recycling use system in the overall environment of, combined with our existing second-hand materials market trends, draw lessons from foreign mature system and experience, put forward a comprehensive universities, intermediate platform, students participate in tripartite depth high school used textbooks circulating use system construction plan, so as to effectively improve the material utilization rate of the ultimate goal.

\section{CurRent Situation of Recycling Utilization OF SECOND-HAND TEXTBOOKS IN UNIVERSITIES}

At present, our country university textbook supply system is actually to buy of, by colleges and Universities Teaching Department of unified purchase, issuance, use life for about a semester, after graduation, except for a few professional books, to the waste paper processing sold to the recycle bin or idle discarded, resulting in enormous waste. To this end, a large number of domestic experts and scholars have more than one call to promote the recycling system of textbooks in the country [2-4]. It is understood, Hubei University of technology has begun to implement local textbooks independent selection system, Hubei University of technology in the large first and second grade students with textbooks, unified order book system, and high grade four students is by the faculty lecturer selected new semester textbook version information, uploaded to the materials science, Academic Affairs Division of external publicity, students according to their own needs ordering new textbooks or purchase in previous years old textbooks. In the connotation of the Hubei University of technology cover a variety of materials purchase system, with adequate representation. In this regard, the author in Hubei University of technology as an example, "used college textbooks circulating use" launched an investigation.

In this survey, a total of 353 copies of the survey questionnaire on the recycling of second-hand textbooks on the University, recycling 320 valid questionnaires, the recovery rate of $90.65 \%$. Through the questionnaire data for statistics and analysis, obtained the following results: college students only $23.43 \%$ of students in the hands of hardly used in the old textbooks and $76.57 \%$ students to accept and use the old teaching material; including $40.01 \%$ of students through the old university bookstore or online used book websites channels to buy the old textbooks, otherwise $24.38 \%$ of students from sister school, senior hands borrow old textbooks. Data show that, in the context of open selection of materials selected, most students are able to accept and use the old teaching materials. Also on the purchase price of the old textbooks, $44.69 \%$ of the students said willing to accept 8-10 yuan per the price and $29.06 \%$ of the students said would accept a 6-8 yuan per the price, $23.13 \%$ of the students expressed the hope that through 
negotiation to determine the transaction price; the author visited Hubei University of Technology surrounding the three old bookstore, learned the old bookstore cost recycling of old materials about 1-2 yuan per the, each of the old materials recycling process can get to 5-8 yuan per the gross profit. It can be seen that the market is quite considerable in the recycling use of the old textbooks in Colleges and universities.

In addition, through in-depth interviews with the old bookstore of the three universities in Hubei University of Technology, further understanding of the existing state of the secondary teaching materials market.

TABLE I. INTERVIEW RECORDS OF SECOND-HAND BOOKSTORES IN UNIVERSITIES

\begin{tabular}{|c|c|c|c|}
\hline $\begin{array}{l}\text { Second-hand } \\
\text { bookstores }\end{array}$ & $\begin{array}{l}\text { College student } \\
\text { Bookstore }\end{array}$ & $\begin{array}{c}\text { Jinfeng old } \\
\text { bookstore }\end{array}$ & $\begin{array}{c}\text { Qili old } \\
\text { bookstore }\end{array}$ \\
\hline $\begin{array}{l}\text { Category of } \\
\text { recycling }\end{array}$ & $\begin{array}{l}\text { Recycling all } \\
\text { kinds of books } \\
\text { except waste } \\
\text { paper }\end{array}$ & $\begin{array}{l}\text { Recycling all kinds } \\
\text { of books except } \\
\text { waste paper }\end{array}$ & $\begin{array}{l}\text { All books on } \\
\text { the line } \\
\text { except waste } \\
\text { paper }\end{array}$ \\
\hline $\begin{array}{l}\text { When and } \\
\text { how }\end{array}$ & Yes & No & Yes \\
\hline $\begin{array}{l}\text { Whether to } \\
\text { set point }\end{array}$ & Yes & No & Yes \\
\hline $\begin{array}{l}\text { Whether to } \\
\text { provide room } \\
\text { service }\end{array}$ & $\begin{array}{l}\text { All the time, } \\
\text { mainly through } \\
\text { the graduates to } \\
\text { buy the old } \\
\text { textbooks }\end{array}$ & $\begin{array}{l}\text { All the time, mainly } \\
\text { through the waste } \\
\text { recycling station to } \\
\text { buy old textbooks }\end{array}$ & $\begin{array}{l}\text { All the time, } \\
\text { mainly } \\
\text { through the } \\
\text { graduates to } \\
\text { buy the old } \\
\text { textbooks }\end{array}$ \\
\hline $\begin{array}{l}\text { Recycling } \\
\text { standards }\end{array}$ & $\begin{array}{l}\text { According to the } \\
\text { number of books, } \\
1 \sim 2 \text { yuan per } \\
\text { book; according } \\
\text { to the weight of } \\
\text { the book, } 1.4 \text { yuan } \\
\text { per kilogram }\end{array}$ & $\begin{array}{l}\text { According to the } \\
\text { number of books, } \\
3 \sim 6 \text { yuan per book; } \\
\text { according to the } \\
\text { weight of the book, } \\
1.6 \text { yuan per } \\
\text { kilogram }\end{array}$ & $\begin{array}{l}\text { According to } \\
\text { the number of } \\
\text { books, } 1 \sim 2 \\
\text { yuan per } \\
\text { book; } \\
\text { according to } \\
\text { the weight of } \\
\text { the book, } 1 \\
\text { yuan per } \\
\text { kilogram }\end{array}$ \\
\hline $\begin{array}{c}\text { Sales } \\
\text { standards }\end{array}$ & $\begin{array}{c}\text { Retail, 5-8 yuan } \\
\text { per book }\end{array}$ & $\begin{array}{c}\text { Retail, } 8-10 \text { yuan } \\
\text { per book }\end{array}$ & $\begin{array}{l}\text { Retail, } 6 \text { yuan } \\
\text { per book }\end{array}$ \\
\hline
\end{tabular}

According to the disclosed in Hubei University of technology in the secondhand bookstore bosses, each of the old bookstore mainly in that year's graduates graduation stage before and after the expansion of old materials recycling, besides seldom have promotional activities. Therefore, every year at least more than half of the students at graduation will choose the university several years to accumulate old textbook sold waste recycling station personnel, and the inflow of waste recycling of old materials, except for a small part of the old textbooks were old bookstore owner subscription, most of the old textbooks will eventually recycling station staff to sell pulp mill or greater recycling station caused great waste. In addition, the old bookstore bosses often encounter students home purchase they don't stock materials or counseling information, due to the derailment of the phenomenon in the actual demand of inventory versions of textbooks and students, and caused a new round of inventory crisis, for occlusion of the key information of second-hand materials trading process, the old bookstore owners also deeply headaches. Due to long-term inventory backlog, most of the old teaching material after recycling sorting, except do some brief repair work, basically had no other treatment, a lot of old textbooks after long-term use, will inevitably have some potential health and safety risks, it hasn't caused the old bookstore owner attaches great importance to.

Accordingly we can infer, existing used college textbook market has not yet formed a relatively unified perfect entity system and related factors in the college secondary materials recycling process, colleges and universities, the old bookstore, waste recycling station, college students, second-hand textbooks between remaining in a one-sided contact, has not yet formed a diversified interchange information communication channels. This point, for the establishment of a healthy college used textbooks recycling is extremely unfavorable, but also blocking the use of college textbooks to achieve a difficult problem of scale efficiency.

\section{SECOND-HAND TEXTBOOKS RECYCLING SySTEM CONSTRUCTION PROGRAM}

In western developed countries, for the second-hand materials recycling, at present, there are mainly three kinds of solutions: one is [5], the establishment of national public system of textbooks, teaching materials to all countries, students have the right to use, the general life of 5-6 years; the second is the construction of second-hand textbook market, and to encourage students to purchase and the use of the old teaching materials, to improve the utilization rate of materials through market regulation, this scheme is mainly applied to the primary school to the high school stage, in the revision cycle of these countries textbooks in general 6-7 years; the last one is free of charge by the school to provide teaching materials, students can use the teaching classes and learning at the same time, to strengthen the ideological education of the propaganda, cherish and protect the students spontaneously to achieve teaching materials recycling, the service life of 3 years in general. Is the present situation of our country, the three schemes currently do not have the conditions in the higher education stage carried out, but the second option to be appropriate modification and improvement to the unfolding smoothly in our country, and can achieve good results.

In this regard, from the current situation of recycling of used textbooks in our country, the use of "5W1H" question technology [6] to work on the construction of recycling system of used textbooks in Colleges and universities.

By Table II and table III for the current situation of the secondary materials recycling of " $5 \mathrm{~W} 1 \mathrm{H}$ " questioning of the first two questions, we can clearly learn the second-hand materials recycling use of the core of the system consists of the third party on behalf of the table of universities, intermediate platform, college students. In Table IV in the third question, research and discussed the possibility of further improvement and improvement direction, establish the second-hand materials recycling management information system, realize the secondhand materials recycling of informatization, in order to reduce the labor cost, improve work efficiency. According to this, we 
can draw a relatively perfect secondary teaching materials recycling system structure as shown below:

Used college textbooks recycling system, the intermediate platform by directly from college students in recycling old textbooks were unified inventory reserve, in each semester before the end when the college teachers to determine the new

TABLE II. "5W1H" FOR THE FIRST TIME TO ASK QUESTIONS

\begin{tabular}{|c|c|c|}
\hline $\begin{array}{l}\text { Inspection } \\
\text { point }\end{array}$ & $\begin{array}{c}\text { The first time to ask } \\
\text { questions }\end{array}$ & Answer \\
\hline Objective & What to do (What) & $\begin{array}{c}\text { The recycling of used } \\
\text { textbooks in Colleges and } \\
\text { Universities }\end{array}$ \\
\hline Reason & Why to do (Why) & $\begin{array}{l}\text { To improve the utilization of } \\
\text { teaching materials }\end{array}$ \\
\hline Time & Time to do (When) & $\begin{array}{c}\text { After the beginning of each } \\
\text { semester, lasts until the end } \\
\text { of the semester. }\end{array}$ \\
\hline place & $\begin{array}{l}\text { Place where to do } \\
\text { (Where) }\end{array}$ & Within the University \\
\hline personnel & Staff who do (Who) & College Students \\
\hline Method & $\begin{array}{l}\text { Method how to do } \\
\text { (How) }\end{array}$ & $\begin{array}{l}\text { A large number of recycling } \\
\text { old textbooks, through } \\
\text { sorting, repair, disinfection } \\
\text { and other unified treatment, } \\
\text { to ban the sale of classes for } \\
\text { the unit } \\
\end{array}$ \\
\hline
\end{tabular}

TABLE III. "5W1H" FOR THE SECOND TIMES TO ASK QUESTIONS

\begin{tabular}{|c|c|c|}
\hline $\begin{array}{c}\text { Inspection } \\
\text { point }\end{array}$ & $\begin{array}{c}\text { The second times to } \\
\text { ask questions }\end{array}$ & Answer \\
\hline Objective & $\begin{array}{c}\text { Whether it is } \\
\text { necessary }\end{array}$ & Yes \\
\hline Reason & $\begin{array}{c}\text { Why should we do } \\
\text { this }\end{array}$ & $\begin{array}{c}\text { Save resources, reduce the } \\
\text { economic burden of college } \\
\text { students, improve the } \\
\text { comprehensive ability }\end{array}$ \\
\hline Time & $\begin{array}{c}\text { Why should we do it } \\
\text { at this time }\end{array}$ & $\begin{array}{c}\text { During this period of time } \\
\text { the students are at school, } \\
\text { and the recycling work takes } \\
\text { a lot of time. }\end{array}$ \\
\hline Place & $\begin{array}{c}\text { Why should we do it } \\
\text { here }\end{array}$ & $\begin{array}{c}\text { Our customers are college } \\
\text { students. }\end{array}$ \\
\hline Personnel & $\begin{array}{c}\text { Why do we need this } \\
\text { person to do }\end{array}$ & $\begin{array}{c}\text { Students can better } \\
\text { communicate with students } \\
\text { and obtain teaching } \\
\text { information }\end{array}$ \\
\hline Method & Why do we need to \\
do this & $\begin{array}{c}\text { The elimination of second- } \\
\text { hand textbooks health risks, } \\
\text { improve the quality and core } \\
\text { competitiveness }\end{array}$ \\
\hline
\end{tabular}

TABLE IV. "5W1H" FOR THE THIRD TIMES TO ASK QUESTIONS

\begin{tabular}{|c|c|c|}
\hline $\begin{array}{c}\text { Inspection } \\
\text { point }\end{array}$ & $\begin{array}{c}\text { The third times to ask } \\
\text { questions }\end{array}$ & Answer \\
\hline Objective & $\begin{array}{c}\text { Is there any other } \\
\text { more appropriate } \\
\text { objects }\end{array}$ & No \\
\hline Reason & $\begin{array}{c}\text { Whether do we need } \\
\text { to do these things? }\end{array}$ & No \\
\hline Time & $\begin{array}{c}\text { Is there any other } \\
\text { more appropriate time }\end{array}$ & No \\
\hline Place & $\begin{array}{c}\text { Is there any other } \\
\text { more suitable location }\end{array}$ & $\begin{array}{c}\text { No there any other } \\
\text { more suitable person }\end{array}$ \\
\hline Personnel & $\begin{array}{c}\text { There are no other } \\
\text { more appropriate } \\
\text { methods and tools }\end{array}$ & $\begin{array}{c}\text { Establish management } \\
\text { information system and } \\
\text { realize information operation }\end{array}$ \\
\hline & \multicolumn{2}{|}{} \\
\hline
\end{tabular}
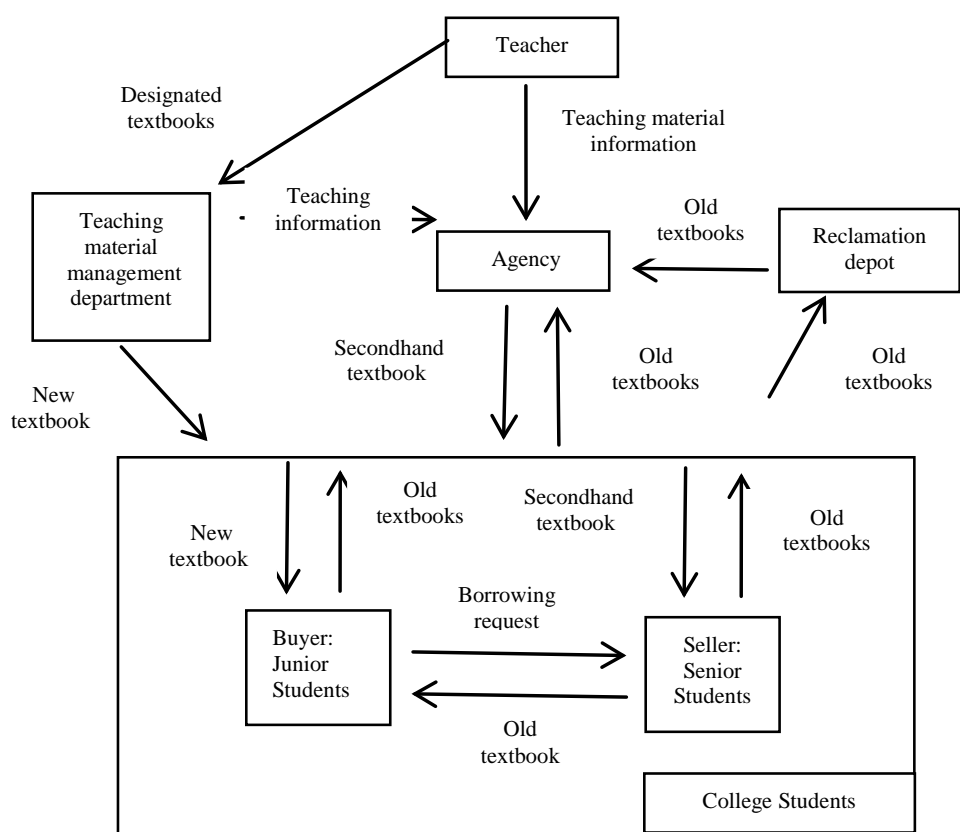

Fig. 1. The second-hand textbooks recycling system structure in Colleges and Universities

semester textbook version information, either directly or through textbooks provide new semester is about to use the textbook version information to the middle platform, platform intermediate is accordingly from waste recycling station to subscribe for the old teaching material in a unified treatment with only the inventory, for the whole school faculties class bulk supply, these second-hand textbooks again put into circulation field, realizes the secondary use value, cycle until the final cannot be use again so far.

In the secondary materials recycling process, by the intermediate platform overall planning and operations, many universities, college students, waste recycling and other members of the woven together to form a relatively perfect marketing network, which will effectively promote the secondhand materials circulation utilization of the process. Therefore, the core of the whole college teaching materials recycling system is the key element of the middle platform. In order to meet the requirements of the above functions and requirements, 
the intermediate platform should have the following software, hardware and personnel, and other necessary conditions:

1) the establishment of a management information system for the collection, processing, storage and dissemination of secondhand materials, the two sides of the supply and demand information, billing information;

2) the establishment of secondary materials recycling procurement, marketing team, to expand the scale and influence of second-hand textbooks recycling market;

3) to create a warehouse, including transport, repair, disinfection and classification coding and other infrastructure;

4) to establish a friendly and cooperative relationship with the library, and to obtain the technical guidance of the library;

5) the establishment of friendly cooperative relations with the teaching materials, to obtain the new semester version of the teaching materials and other information;

6) adequate human resources, perfect management information system, supply and marketing plan and scheduling, system maintenance, management norms, and other basic settings.

College secondary teaching materials recycling system mainly consists of three sections: college, middle platform, college students. As the platform of key elements of logistics and information flow, such as shown in Figure 2, in the secondhand materials recycling system, in the middle of the platform as a link, colleges and universities from the adjacent auxiliary, college students deep participation, thus effectively promote second-hand textbooks recycling to achieve economies of scale and improve the utilization rate of materials.

Intermediate platform management activities

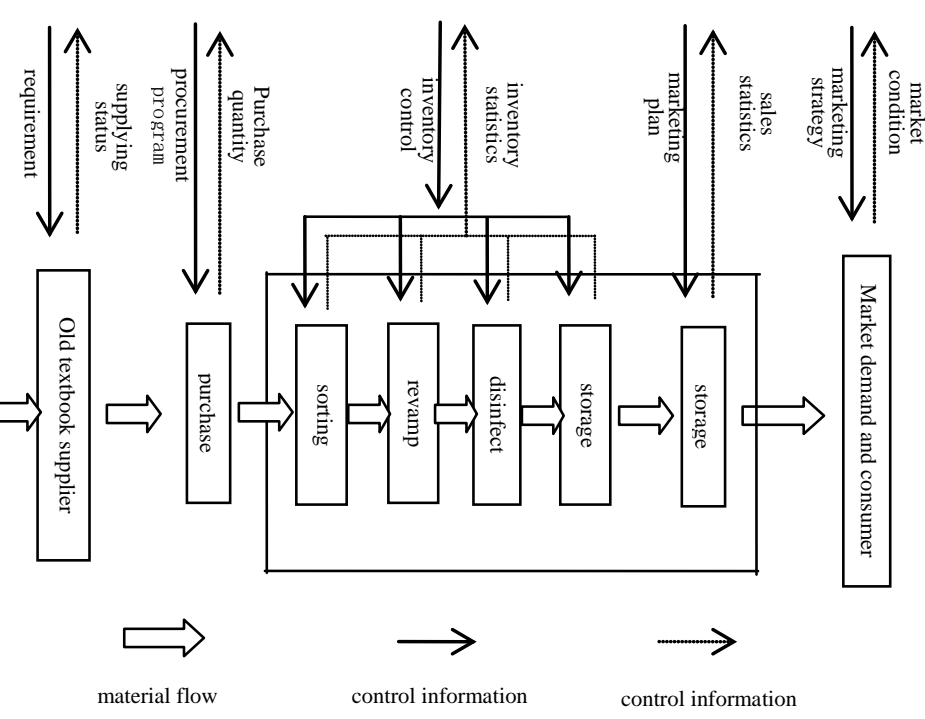

Fig. 2. Logistics and information flow of the intermediate platform

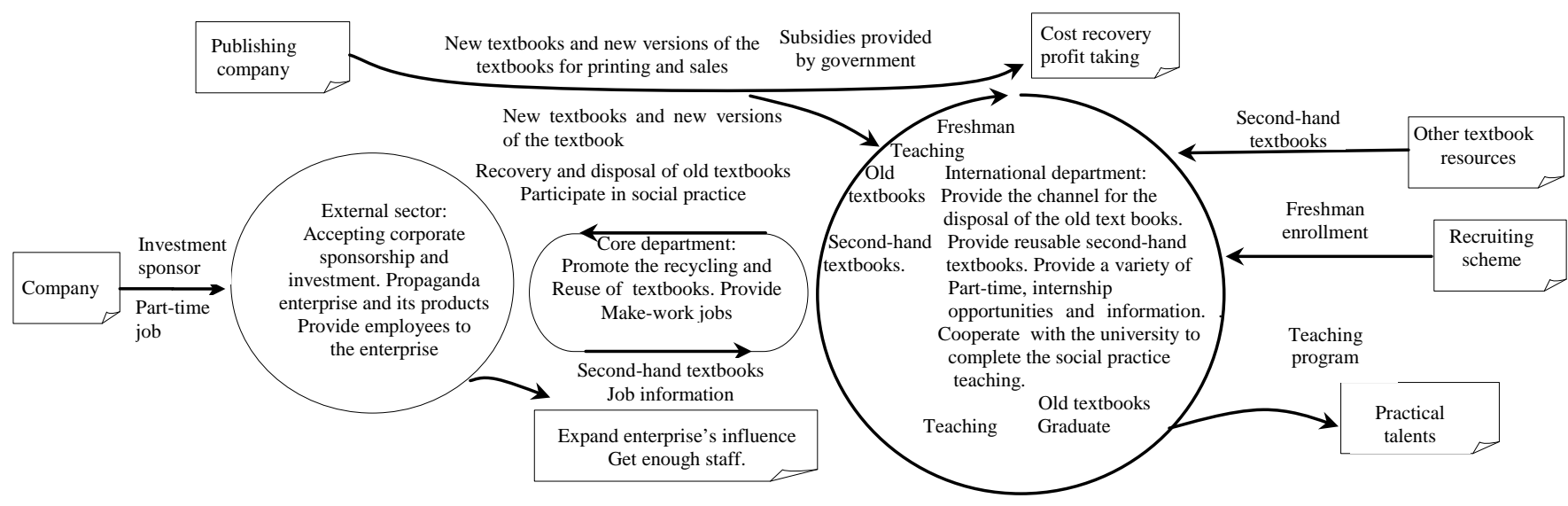

Fig. 3. The second-hand textbooks recycling system in Colleges and Universities

As shown in Figure 2, in the second-hand materials recycling system, the school to provide policy support, Open University teaching material purchase system, allowing students to purchase through other channels designated school textbooks; secondly, teaching materials, and the middle platform with each other, sharing the new semester teaching material information, and make operation convenient intermediate platform of supply and marketing the plan; in addition, the library and the middle platform to establish friendly relations of cooperation, to provide technical guidance books, repair disinfection and storage, eliminating the longterm use of the second-hand materials fouling health risks; in addition, the intermediate platform hosted and run by the students, can be more convenient to establish close contact with college students, through the middle platform in operation profit, recovery and subsidies in the old materials processing and sales in the process of phase Close the personnel, can maintain the platform the benign operation for a long time, promotes the University second hand teaching material the recycling use.

\section{SUMMARY AND DISCUSSION}

By establishing the teaching material recycling system, set up by the students to maintain operations used college textbooks circulating use system, and thus for the hub mobilize 
more students pay attention to and participate in; acquired through the college textbook recycling proceeds to pay for participation in the operation of college students deserve the pay to motivate and stimulate and improve University group to the second-hand materials recycling degree of attention and active participation in the warm, doing things through the organization and promote the recycling of textbooks in Colleges and universities in the textbook recycling, processing, marketing and other matters relating to the exercise of college students comprehensive ability. In a word, have the understanding of college students not but his college students. Therefore, to college students' group led the second-hand materials recycling utilization system, to further mobilize most college students' attention and participation enthusiasm and initiative to form the second-hand materials circulation utilization system of a virtuous circle. Secondly, to the old materials recycling utilization system link form all over the school to the college students in the circulation of information in the context, and foreign related enterprises sponsorship and investment, to provide work, part-time social practice of channels and information, with respect to the various intermediary website, social intermediary and provide unified school social practice channel, circulating in the group of college students social practice information on college students more attractive, at the same time, it can provide more information on social practice, let more students access to social practice, to assist in the completion of practical education high school.

The second-hand materials recycling utilization system as the hub, universities, enterprises, unit of choose and employ persons together and provide part-time business, promotion, labor and other aspects of information, colleges and universities from adjacent to the guide, students from access to a variety of into the social practice of channels and information, in the spare time deeply society, social awareness, to learn to do, learn to behave, learn to move the brain, learn how to learn, to complete the process of socialization, growth for the practical talents. This point, to promote the recycling of used textbooks in Colleges and universities is a few beneficial, but also in China's existing conditions can quickly and effectively improve the efficiency of teaching materials, building materials recycling system of the best program.

\section{REFERENCES}

[1] Zhang Dongjiao. Comparative study of comparative education research [J]. systems of textbook use in compulsory education between China and the United States, 2003 ,pp. 77-80.(In Chinese)

[2] Chen Xiaoxia, Zhang Kun. Analysis and Discussion on the recycling and utilization of university teaching materials [N]. Journal of Agricultural University of Hebei (agriculture and Forestry Education Edition), 2013.6-15 ,pp. 45-48.(In Chinese)

[3] Hu Sonia. Research on current situation and Countermeasures of [J]. Reform and opening materials recycling college, 2010.8, pp. 154. (In Chinese)

[4] Xuying. College students old recycling to use via and Countermeasures -Taking Tibet University as an example [J]. Academy |XUEYUAN 2014 ,pp. 54, 76.(In Chinese)

[5] Ge Qiufang, Zhao Qing, Yang Shilong, Zhao Yan, Chen Weihua, Tao Fang. Look abroad how to recycle the use of textbooks [J]. Foreign dynamics, 2008.13,pp. 62-63.(In Chinese)

[6] Yi Shuping, Guo Fu. Basic industrial engineering [M].2 ed. Beijing: Mechanical Industry Press, 2013.8.(In Chinese) 